\title{
BEDDEN KOMEN SNELLER VRIJ
}

\section{Dit voorjaar lanceerde E-sites de Stoplicht app om de doorstroom van ziekenhuiszorg naar thuiszorg te versnellen. "Ziekenhuisverpleeg- kundigen kunnen nu makkelijk zelf de doorverwijzing naar de thuiszorg regelen.'}

De Stoplicht app is een app en dashboard om de doorstroom van ziekenhuis naar thuis te vereenvoudigen. 'Het kost heel veel tijd om een patiënt overgeplaatst te krijgen', licht Helma van Meijl toe, marketing coördinator van E-sites. 'Je moet bellen met de verschillende thuiszorgorganisaties om te kijken of er plaats is. Via de Stoplicht app kan het veel sneller; het bespaart tijd en dus geld.'

Het is allemaal begonnen bij het Amphia Ziekenhuis in Breda. Eerst was er een website waarop werd bijgehouden bij welke thuiszorgorganisaties plek was, vertelt Van Meijl. 'Maar die website was niet altijd up to date.' Daarna gebruikte het ziekenhuis een Excel-bestand. 'Dat was de eerste vorm van de Stoplicht app. Daarbij werden al drie kleuren gebruikt: rood voor "niet beschikbaar", oranje voor "in overleg" en groen voor "beschikbaar”. Het Amphia Ziekenhuis vroeg ons iets te verzinnen dat het Excel-bestand kon vervangen.'

Maart vorig jaar is de Stoplicht app gelanceerd. Dit jaar heeft de app een white label gekregen wat betekent dat ook andere ziekenhuizen en thuiszorgorganisaties er gebruik van kunnen maken. Van Meijl: 'We hadden al afspraken met andere ziekenhuizen staan, maar die zijn door corona uitgesteld. Wel gaan huisartsen in de regio gebruikmaken van de Stoplicht app.'

De ervaringen met de app bij het Amphia ziekenhuis zijn volgens Meijl hartstikke positief. 'Het scheelt de transferverpleegkundige veel werk. Ziekenhuisverpleegkundigen kunnen nu makkelijk zelf de doorverwijzing naar de thuiszorg regelen. De doorstroming verloopt sneller, ziekenhuisbedden komen sneller vrij. Ook bij de spoedeisende zorg. Én de app werkt als katalysator voor de verbetering van onderlinge contacten.'

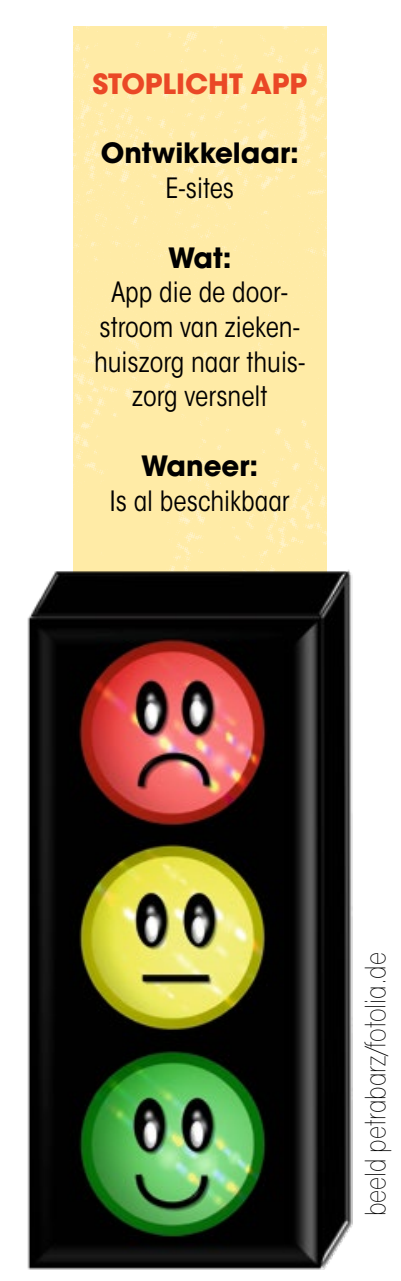

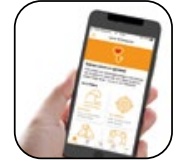

COVID-19 RESPONSE-APP Ontwikkelaar: See Your Sparks

De Covid-19 Response-app is een hulpmiddel voor artsen en verpleegkundigen om vitaal te blijven onder hoge druk. Het is ook een instrument voor leidinggevenden om de druk binnen het team bespreekbaar te maken. Door metaforen te gebruiken, creëert de Covid-19 Response-app een gezamenlijke taal met zes pijlers die eenvoudig zijn te onthouden: De Storm, Het Kompas, De Boot, De Reddingsboei, Het Anker en Het Roer.

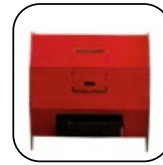

\section{BEPPIE \\ Ontwikkelaar: Nedap}

Beppie is een 'app apparaat' voor in een verzorgings- of verpleeghuis. Met Beppie blijven bewoners die niet met een smartphone om kunnen gaan, toch gemakkelijk in contact met hun familie en geliefden. Beppie zet een fysieke ansichtkaart, geschreven door opa en oma, om in een appje op de smartphone. Andersom wordt een appje op de smartphone omgezet in een fysieke ansichtkaart. Beppie ziet eruit als een kleine brievenbus.

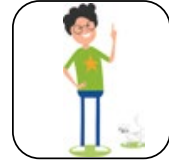

MIIJNZELFIE

Ontwikkelaar: GGZ Oost Brabant en NEXUS

Met behulp van de webapplicatie MijnZelfie is het medisch dossier toegankelijk voor cliënten met een psychiatrische aandoening in combinatie met een (licht) verstandelijke beperking. MijnZelfie helpt cliënt en hulpverlener om niet alleen te focussen op de psychiatrische stoornis. Alle voor de behandeling en begeleiding relevante aspecten worden visueel in kaart gebracht. 